\title{
A MORTE NO AMBIENTE DOMÉSTICO: ritos fúnebres no Vale do Paraiba Fluminense Oitocentista (Freguesia de Piraî)
}

\author{
Aguiomar Rodrigues Bruno* \\ Geovani Dias Pereira**
}

RESUMO: Missas pelas almas, orações, o cortejo fúnebre, o sepultamento: os ritos fúnebres eram vividos na e pela coletividade no século XIX. Tomar parte nesses ritos ajudava a comunidade a lidar com a crise que se desenhava com partida de um de seus membros para o além. Contudo, a preparação para a morte se iniciava na casa do moribundo, antes mesmo de sua partida. Este trabalho pretende analisar como a iminência da morte transformava a casa do doente, um ambiente usualmente doméstico e profano, num espaço heterotópico onde ritos específicos construíam uma atmosfera de exceção. Ali, os limites entre o sagrado e o profano, o público e o privado, se confundiam; a iminência física da morte ressignificava a própria morte, transformando seu caráter desagregador em uma expectativa de transcendência que, aliada à crença de uma boa morte, reconciliava a comunidade consigo mesma e com o divino.

PALAVRAS-CHAVE: Ritos fúnebres; Ambiente Doméstico; Heterotopia; Igreja Católica

\section{DEATH AT DOMESTIC ENVIRONMENT: funeral rites on the Fluminense Paraiba Valley in the XIX ${ }^{\text {th }}$ century (parish of Pirai)}

ABSTRACT: Masses for the souls, prayers, the funeral procession, the burial: the funeral rites were lived in and by the community in the $\mathrm{XIX}^{\text {th }}$ century. Taking part in these public rites used to help the community to deal with the crisis that was drawn from the departure of one of its members to beyond. However, the preparation for death was initiated in the moribund's house, even before his departure. This paper intends to analyze how the imminence of death used to transform the sick's house, an usually domestic and profane environment, to a heterotopic place where specific rites built an atmosphere of exception. There, the boundaries between the sacred and the profane, the public and the private, were confused; the physical imminence of death meant death itself, transforming its disintegrating character into an expectation of transcendence which, tied to the belief of a good death, reconciled the community with itself and with God.

KEYWORDS: Funeral rites; Ddomestic environments; Heterotopy; Catholic Church.

\section{LA MUERTE EN EL AMBIENTE DOMÉSTICO: ritos funerarios en el valle del Paraiba Fluminense em el siglo XIX (parroquia de Pirai)}

RESUMEN: Misas por las almas, las oraciones, la procesión del funeral, el entierro: los ritos funerarios se vivían en y por la comunidad en el siglo XIX. La participación en estos rituales ayudaba a la comunidad por enfrentar a la crisis que se dibujaba con la partida de uno de sus miembros al más allá. Sin embargo, la preparación para la muerte se iniciaba en la casa del moribundo, incluso antes de su partida. Este trabajo analiza cómo la inminencia de la muerte transformaba la casa del paciente, en general un ambiente doméstico y profano, en un espacio heterotópico donde ritos específicos construían un ambiente de excepción. En este caso, los límites entre sagrado y profano, público y privado, se confundían; la inminencia física de la muerte atribuía un otro significado a la muerte misma, transformando su carácter disgregador en una expectativa de trascendencia que, relacionada con la creencia de una buena muerte, reconciliaba la comunidad consigo misma y con el divino.

PALABRAS-CLAVE: ritos funerários; ambiente doméstico; Heterotopía; Iglesia Católica.

\footnotetext{
* Licenciado em História pelo Centro Universitário Geraldo Di Biase (UGB). Atualmente, é doutorando em História pela Universidade Federal do Estado do Rio de Janeiro (UNIRIO). O autor escreveu as seções "A preparação para a morte: o testamento." e "O ambiente doméstico: os ritos fúnebres". Contato: Av. Pedro Calmon, 550 - Cidade Universitária, 21941-901, Rio de Janeiro - RJ - Brasil. E-mail: donkoiote@ hotmail.com.

Especialista em História Moderna pela Universidade Federal Fluminense (UFF). Este autor escreveu a Introdução, a seção "O ambiente doméstico: a preparação para a morte", e as considerações finais. Contato: Universidade Federal Fluminense, R. Tiradentes, 198 - Ingá, 24210-510 Niterói-RJ, E-mail: geovani.dias@ymail.com
} 


\title{
Introdução
}

\begin{abstract}
Por trás dos grandes vestígios sensíveis da paisagem, os artefatos ou as máquinas, por trás dos escritos aparentemente mais insípidos e as instituições aparentemente mais desligadas daqueles que as criaram, são os homens que a história quer capturar. Quem não conseguir isso será apenas, no máximo, um serviçal da erudição. Já o bom historiador se parecesse com o ogro da lenda. Onde fareja carne humana, sabe que ali está sua caça.
\end{abstract}

Desde os tempos de Heródoto e Tucídides, escreve-se História. Por longo tempo, contudo, a História foi uma narrativa dos acontecimentos políticos e militares. Uma História dos grandes feitos e dos grandes homens. Era então a hegemonia da História Política, do registro escrito enquanto tal, da versão oficial, que só fez aumentar no século do positivismo. Nele, a obsessão da História por afirmar-se enquanto ciência conduziu a um estreitamento de métodos, de temas e de objetos de interesse, que desde o Iluminismo a História tentava expandir. Vozes como as de Michelet $^{2}$ e Burckhardt ${ }^{3}$, que se interessavam por temas tão diversos como a religião, o Estado e a cultura, ou mesmo por uma "história dos subalternos", eram vozes dissonantes ${ }^{4}$.

O século XX, em comparação, assistiria a uma revolução. Assim se referiu Peter Burke ao movimento liderado pelos historiadores franceses Marc Bloch ${ }^{5}$ e Lucien Febvre ${ }^{6}$, em sua famosa obra "A Escola dos Annales: a revolução na historiografia"7 . Nessa obra, Burke compara o impacto do movimento historiográfico iniciado pelos editores da Revista Annales d'Histoire Économique et Sociale com a mais marcante revolução política no mundo ocidental: a revolução francesa. Pode parecer exagero, ou até mesmo puro preciosismo dos profissionais do campo: o fato, entretanto, é que a Escola dos Annales deu grande visibilidade e influência a um tipo de historiografia que possibilitou superar os limites do fazer historiográfico, redefinindo inclusive o papel do historiador ${ }^{8}$.

A História dos Annales era muito mais que a História dos grandes homens e acontecimentos: era uma história da gente miúda, dos “subalternos". Mas também das gentes "eminentes" que antes estavam ausentes da narrativa dos heróis da pátria. E na busca da gente comum, de farejar os vestígios da "carne humana", o historiador direcionou sua curiosidade para as pessoas, suas manifestações culturais, suas relações, suas crenças e misticismos, suas ideias e representações da realidade, seus símbolos e signos, o afluir e refluir de sua moeda, as transformações espaciais e temporais de suas sociedades.

A busca e compreensão dos mais variados vestígios humanos impulsionou o historiador dos Annales a dialogar com diversas disciplinas das Ciências Humanas - 
Sociologia, Antropologia, Geografia, Arqueologia, Economia, Linguística, Literatura etc. apropriando-se de suas discussões, ferramentas, métodos e conceitos. A partir daí, descortinou-se uma profusão de objetos e fontes infindáveis ao pesquisador. $\mathrm{Na}$ mesma proporção, surgiram diversos campos de pesquisa. É nesse contexto que surge uma história das atitudes diante da morte, como um dos campos mais interessantes da chamada "historia das mentalidades".

Para Michel Vovelle, essa produção historiográfica compreende que "todas as representações da morte estão imersas em um contexto ou em um banho cultural que é propriamente o tecido da História"9 . Dessa forma, o historiador da morte ensina que muito se pode aprender sobre a vida dos povos antigos ao estudarmos como estes concebiam o além e experimentavam a morte, de si e dos outros. Afinal, os estudos desenvolvidos nesse campo não se limitaram à percepção da morte e suas apropriações culturais, mas também, “[ao] ser humano, o viver, a cultura se relacionando com o natural"10.

Philippe Ariès ${ }^{11}$ - assim como Vovelle - tornara-se expoente de uma escola francesa da historiografia da morte. Na esteira desses pensadores, trabalhos inovadores foram desenvolvidos no Brasil, como os de João José Reis ${ }^{12}$, Adalgisa Arantes Campos ${ }^{13}$, Claudia Rodrigues $^{14}$, Luiz Lima Vailati ${ }^{15}$, entre outros. Todos esses trabalhos situam suas preocupações sobre o viver do indivíduo a partir de suas apropriações e produções materiais e imateriais em torno da morte e do morrer.

É nesse contexto que nos propomos a analisar os ritos fúnebres, especialmente aqueles realizados nos espaços domésticos. A concepção da morte e as práticas ritualísticas a ela associadas são reflexos da cultura e do contexto histórico da sociedade em que foram produzidas. Tanto os ritos como os objetos envolvidos, incluindo o próprio espaço fúnebre, são determinantes para a construção da morte no imaginário coletivo. Dessa forma, ao examinarmos como se dão os ritos de separação entre vivos e mortos, podemos evidenciar como as pessoas concebem não apenas a morte, mas também a própria vida. E quando realizada no contexto das sociedades tradicionais, esse tipo de análise se mostra particularmente interessante, uma vez que nelas a morte e o imaginário a ela associada ocupavam um espaço consideravelmente maior no cotidiano das pessoas.

Utilizaremos como fontes de análise as narrativas de diversos memorialistas, dados e narrativas obtidos dos trabalhos de diversos pesquisadores em espaços outros, assim como testamentos e inventários da freguesia de Piraí, no sul da província do Rio de Janeiro. Tomaremos essas fontes como vestígios para reconstruir e analisar os ritos produzidos sobre e 
nos ambientes privados dessa freguesia, aproximando-os de situações análogas descritas e analisadas em outras paragens. Partiremos, assim, de um método de análise microhistoriográfico, por acreditarmos que através de fragmentos podemos “[...] enxergar uma questão social mais ampla ou um problema histórico ou cultural significativo"16. Apropriarnos-emos também do cabedal teórico desenvolvido por Michel Foucault para definirmos os ambientes domésticos em contexto fúnebre como espaços de heterotopia ${ }^{17}$.

\section{A preparação para a morte: o testamento}

Desde a Baixa Idade Média, o ato de testar se constituiria paulatinamente numa expressiva medida de preparação para a morte, transformando-se em instrumento soteriológico $^{18}$. A partir do século XV, a Igreja passou a considerá-lo quase um sacramento ${ }^{19}$, e o tema tornou-se presença constante dos textos do direito canônico. As "Constituições Primeiras do Arcebispado da Bahia", importante documento do direito canônico brasileiro do século XVIII, enfatizava o caráter salvífico dos testamentos, ao prescreverem que "quando [se] escreverem, e fizerem testamentos de algumas pessoas, tenhão em primeiro lugar intento do que convém a salvação do testador $[\ldots]^{\prime 20}$.

Além dos textos canônicos, um tipo de literatura devocional também se ocupou da preparação para a morte: eram os artes moriendorum, espécies de "manuais da boa morte". Surgidos na Europa na passagem do século XV para o XVI, sob a influência da grande angústia do fim da Idade Média, os artes moriendorum proliferaram e encontraram ambiente fecundo para se difundir, sobretudo pelo papel que o clero lhe atribuiu em seu esforço por um maior controle sobre os ritos e representações fúnebres. Entre os séculos XVI e XIX, propagaram-se em profusão tanto no Portugal metropolitano, quando na América Portuguesa. No Brasil imperial, ainda circulavam em quantidade substancial; tanto na freguesia estudada quanto em outras de sua região, diversos exemplares desses "manuais" foram encontrados em bibliotecas particulares ${ }^{21}$, o que nos indica sua influência duradoura na representação da "boa morte" dessas sociedades.

Apesar de escrita em 1707, as "Constituições", juntamente com os "manuais da boa morte", desempenharam importante papel norteador em relação aos desígnios católicos quanto à feitura testamentária, e sua influência se estendeu para além dos setecentos. Até meados do século XIX, os testamentos brasileiros ainda tinham importante conteúdo 
religioso, sendo frequentes as disposições neles contidas que faziam menção à salvação da alma. A freguesia de Piraí, no interior fluminense, não fugia à regra ${ }^{22}$.

Esse mundo em que Piraí se localizava, situado ao sul do Rio de Janeiro imperial, se notabilizou pela produção de café ao longo dos oitocentos. Com farta disponibilidade de terras (fronteira agrícola aberta), uma rede de estradas e caminhos consolidada, uma estrutura de tráfico negreiro montada e volumosa reservas de capitais privados investidos, o Vale do Paraíba fluminense, nessa época, se transformou num complexo cafeeiro aos primeiros sinais de possíveis lucros a partir da expansão da demanda no mercado internacional ${ }^{23}$. Atravessado pelas terras que até ao final do século XVIII compreendia a antiga vila de São João Marcos, cuja base econômica fora o predomínio da cultura canavieira e seus derivados, o povoado de Piraí passaria, após um longo processo político de emancipação (cujo fim se deu em 1838), a figurar nas décadas seguintes como uma das áreas mais prósperas do império - o que podemos atestar pela enorme concentração de cativos que nela vivia ${ }^{24}$.

Independente das questões político-econômicas da época, na freguesia de Piraí, assim como na capital imperial, ou em Salvador, a prática de uma "boa morte" estava diretamente relacionada ao cumprimento das determinações eclesiásticas tridentinas para a obtenção do perdão divino. Nesse período, todo bom católico, independente de suas posses, preocupava-se em ter a "boa morte"; assim, ao perceberem a proximidade da morte, preparavam-se com todo zelo para sua chegada - o que incluía quase necessariamente a escritura de um testamento. João José Reis, em seu clássico estudo sobre a morte na Salvador oitocentista, assinala que "o grande medo era mesmo morrer sem um plano [...]. A preparação facilitava a espera da morte e aliviava a apreensão da passagem para o além" ${ }^{25}$.

O investimento eclesiástico em torno desse perdão tinha um caráter pedagógico: o pensamento constante do fiel em sua própria morte convertia-se numa vida disciplinada e sacramental $^{26}$. Dessa forma, o ritual fúnebre definia um padrão comportamental para bom cristão, o qual adotava práticas consoantes com os dogmas da fé católica que iam além da mera preparação de seu funeral: relacionavam-se, sobretudo à preparação de uma vida cristã. Ademais, o rito fúnebre cumpria um significado simbólico, cujo papel era transpor as tensões sociais produzidas pela morte ${ }^{27}$. Assim, as práticas e representações que povoavam o imaginário coletivo produziam uma gama de imagens variadas da morte, transformando, epistemologicamente, a vida, a morte e a sociedade ${ }^{28}$.

O rito fúnebre de antanho tinha início muito antes da morte do fiel. Por excelência, era por meio do testamento que o bom cristão iniciava esse ritual. A análise detida dos 
testamentos produzidos na freguesia de Piraí até meados do século XIX - ou mesmo depois evidencia esse caráter do fazer testamentário enquanto ato primitivo do rito fúnebre. É o que podemos observar pelo conteúdo do testamento do piraiense Matheus Rodrigues Pinheiro, cuja escritura se deu em 1873:

Em nome de Deos Amem. Eu Matheus Rodrigues Pinheiro, catholico apostólico Romano, em cuja religião nasci, tenho vontade e protesto morrer; este é o meu testamento e ultima vontade. [...] Em eu falecendo, desejo que o meu enterro se faça sem pompa alguma, havendo em tudo a maior modéstia e simplicidade, bem como quero que se diga uma missa de corpo presente, e para essa despesa deixo a quantia de seis centos mil reis, devendo o meu testamenteiro distribuir pelos pobres que não puderem partilhar, o que d'ella sobrar. Deixo a quantia de seis centos mil reis em moeda franca, que será entregue a meu sobrinho José Rodrigues Pinheiro, cuja quantia ele dispôs de modo seguinte: com a metade d'essa quantia ele mandará dizer missas por minha alma e com a outra metade mandará dizer missa cantada a Nossa Senhora do Socorro de sua freguesia e a vontade mandará fazer um jantar a que deverão assistir os pobres, em louvor ao Divino Espírito Santo. [...] Deixo a Irmandade do Santíssimo Sacramento da Villa de Pirahy a quantia de cem mil reis ${ }^{29}$.

Segundo Mary del Priore, os testamentos obedeciam a certa padronização: "iniciavam-se, sempre, por um preâmbulo em que se invocava o nome de Deus ou da Santíssima Trindade [...]"30. Essa forma de apelo encontrada nas introduções testamentárias, mencionando os santos de devoção pessoal e/ou apelando para a corte celestial, foi largamente usada. A ideia era que o moribundo pudesse contar com a intervenção desses advogados poderosos na hora derradeira ${ }^{31}$.

Além da intervenção de forças celestiais, o testamento de Matheus estabelecia certas práticas piedosas a serem adotadas logo após a sua morte - ou seja, no período que ia do funeral aos sufrágios. Entre essas práticas, uma das mais importantes são as doações piedosas para os pobres e para a mais prestigiada irmandade de Piraí, a do Santíssimo Sacramento ${ }^{32}$. Num sentido mais direto, tal prática de legar esmolas aos pobres era um testemunho de piedade cristã altamente valorizada como expediente de salvação. Conforme João José Reis, "os pobres engrandeciam os funerais dos ricos, dando-lhes ainda a oportunidade de lavarem a alma com um ato de caridade. [...] Suas preces eram tidas como especialmente benéficas"33. Desde os tempos medievais, dentro da concepção cristã, o pobre era um elemento escatologicamente necessário à salvação, e a esmola, uma obrigação daqueles que a quisessem atingir ${ }^{34}$. Em pleno século XIX, essa prática medieval ainda era bastante atual. Dessa forma, doando seus bens aos pobres, Matheus barganhava com o sagrado sua passagem para o Paraíso.

Os legados deixados às irmandades podem também ser compreendidos nesse mesmo 
contexto de "barganha com o sagrado". Dentro da perspectiva soteriológica cristã, as irmandades figuravam como verdadeiras intercessoras entre vivos e mortos. Por muito tempo, "as irmandades passaram a considerar a assistência às exéquias a sua principal finalidade" 35 . A esse respeito, o compromisso da já citada Irmandade do Santíssimo Sacramento expressava, em 1860:

$\S 2^{\circ}$ Ter doze missas por sua alma, e catacumba para si e seus filhos até a idade de 14 annos, comprovados com certidão de baptismo,se o Tesoureiro exigir.

$\S 3^{\circ}$ Ser acompanhado pela Irmandade, da matriz só para o cemitério, a qual também é obrigada a assistir aos seus funeraes.

$\S 4^{\circ}$ Ter dobres de sino, opas, tochas e Eça, ou urna nos seus enterramentos ${ }^{36}$.

Dessa forma, quando ocorria a morte de um confrade, a irmandade tinha oportunidade de reafirmar "a sua função por excelência: o trato do enterramento",37. Desde a época do Brasil colonial, essa função nobre e altamente valorizada era incumbência quase exclusiva das irmandades que, por meio dela, reforçavam seu próprio poder e prestígio perante a comunidade. Isso se confirmava inclusive pela aquisição dos legados deixados pelos seus confrades em testamento.

Além das doações aos pobres e legados para a irmandade do Santíssimo Sacramento, o testamento de Matheus estabelecia também a realização dos sufrágios, isto é, orações, missas e esmolas post mortem. A realização desses sufrágios estava atrelada à crença de seu caráter benéfico em relação à salvação da alma no Purgatório.

Dentro da geografia celestial, o destino das almas dependia do "julgamento individual em seguida do falecimento, que, além do inferno, podia ter como resultado a absolvição absoluta" ${ }^{38}$, ou então - e mais comumente - a expiação temporária das culpas menos graves no Purgatório. Segundo a tradição católica, o estado das almas no Purgatório é de absoluta impotência. Por isso, havia a crença na necessidade da intercessão dos vivos e dos santos padroeiros para encurtar a estadia das almas nesse lugar. Esta intercessão se dava fundamentalmente por meio dos sufrágios em memória do defunto, cujo objetivo era exortar aos santos padroeiros que se apiedassem de sua alma e clamassem por seu perdão divino. Além disso, esses sufrágios carregavam um significado simbólico, relacionado à construção de uma representação de beatitude cristã para comunidade que os realizavam e à qual o defunto pertencia, beatitude essa que emprestava inestimável santidade à alma do falecido. 
Figura 1: Nossa Senhora da Conceição.

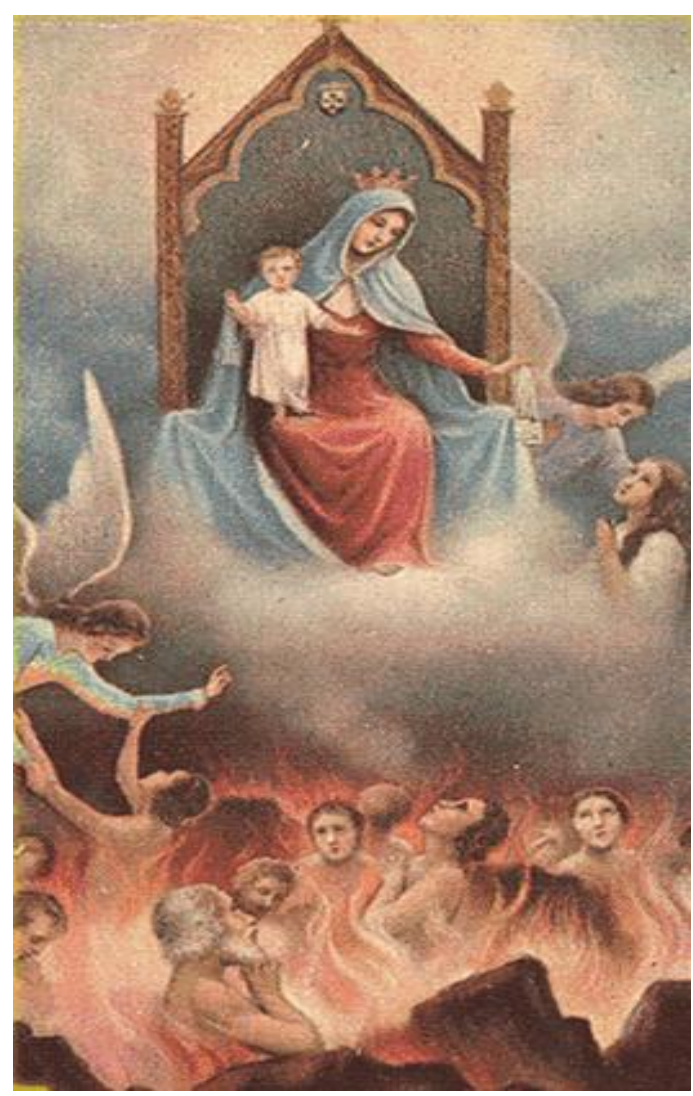

Fonte: disponível em: http://www.amormariano.com.br

Dessa forma, o Purgatório se caracterizava essencialmente como uma região de passagem, "onde os mortos precisavam da ajuda dos vivos, na forma de missas e promessas a santos"39. Daí advém a preocupação de Matheus em deixar, em testamento, missas pagas a serem ditas em favor de sua alma e de sua santa de devoção: Nossa Senhora do Socorro. "Intercedei por nós, ó mãe do Perpetuo Socorro!/ Pelos agonizantes e as almas do Purgatório" 40 . Esta santa era uma das preferidas por aqueles que anseiam por escapar dos tormentos do Purgatório, e frequentemente é representada na iconografia religiosa salvando almas atormentadas.

Podemos observar, nessa passagem, que Matheus não utilizou seu testamento apenas para dispor de seus bens. Antes, ele o usou principalmente para presidir seu próprio rito fúnebre. Por meio do testamento, Matheus determinou em detalhes como deveria ser seu funeral: sem pompa, com uma missa de corpo presente - para a qual destinava parte de seus bens -, e com distribuição de esmolas aos pobres. Além disso, o fiel também explicitou nele seu desejo pela intercessão dos vivos, quando sua alma estivesse padecendo no Purgatório. De fato, a distribuição de seus bens foi pensada fundamentalmente para assegurar essa interseção. 
Dessa forma, podemos afirmar que o testamento de Matheus é exemplar sobre como esse tipo de documento era instrumentalizado, no Brasil do século XIX, como parte do ritual fúnebre, o que, em muitas ocasiões, transformava o ato de testar na primeira etapa do próprio funeral.

\section{O ambiente doméstico: a preparação para a morte}

A Igreja propugnava a seus fieis que escrevessem seus testamentos como forma de se preparar para uma "boa morte". A esse respeito, é importante salientar que ela os advertia de que mandassem escrever suas últimas vontades gozando sempre de plena saúde e em estado de lucidez ${ }^{41}$. Contudo, o mais comum foi que a feitura do testamento ocorresse às portas da morte do testador, quando este se encontrava enfermo e/ou acamado. Foi o que fez o piraiense Manoel José Fernandes Alves, em 1877: "sentindo-me adoentado, resolvi fazer minhas disposições de últimas vontades",42

Como já foi dito, o ato de testar foi fortemente regulamentado pela Igreja, que o elevou à categoria de um quase sacramento para a obtenção de uma "boa morte". Entretanto, os fieis constantemente ignoraram essa regulamentação no que diz respeito ao momento de praticar essa etapa do "rito fúnebre", ressignificando os preceitos da Igreja à sua vontade. Diante dessa constatação, como podemos explicar que os católicos adotassem prática tão oposta àquela que lhe prescrevia a Igreja para alcançar uma "boa morte"?

É possível esboçar uma resposta a esse questionamento, ressaltando que o imaginário católico frequentemente representava a "boa morte" como aquela que não surpreendia o cristão despreparado. Havia uma expectativa de que a morte ocorresse num contexto em que o fiel pudesse controlar suas condições e determinar as de seu próprio funeral. Portanto, era desejável que o fiel não morresse subitamente, mas numa lenta agonia, que lhe permitisse ter tempo de tomar todas as providências para se preparar para a morte - inclusive escrever seu testamento. E o lugar por excelência onde se dava essa agonia deveria ser previsível e amigável; um lugar onde o moribundo pudesse estar cercado dos seus, os quais providenciariam vigilantemente todas as práticas fúnebres indispensáveis para a salvação de sua alma; esse lugar era, portanto, sua própria casa.

[...] a morte fora da casa de morada era e é vista com muita apreensão, como se fosse um acontecimento fora de ordem, fora da ordem natural das coisas. A moradia é o lugar da morte porque é, também, socialmente, o lugar da família, dos vizinhos, dos amigos, daqueles que podem ajudar uma pessoa a bem morrer e que podem pôr 
em pratica os ritos funerários indispensáveis à proteção da casa e da família ${ }^{43}$ (MARTINS, 1983, p. 263).

A partir da formação do Estado burguês, no século XVIII, irá tomar forma a ideia da construção de um espaço público, em detrimento do privado ${ }^{44}$. Consequentemente, surge contra a exacerbação do social um novo padrão de convivência, não mais identificada com a vida na rua, na igreja e na praça, mas no interior de um espaço propriamente privado. Conforme Michelle Perrot ${ }^{45}$, as transformações políticas da época acentuariam no espaço privado seu sentimento familiar, em que a diferenciação dos papeis sexuais colocava uma oposição entre homens (políticos) e mulheres (domésticas).

$\mathrm{Na}$ América Portuguesa, as práticas de sociabilidades eram geralmente públicas e atreladas às cerimônias e devoções religiosas. Nascer, casar-se, ter filhos, entre outros momentos festivos eram marcados por diferentes ritos de passagem, os quais, a despeito de certos aspectos profanos, guardavam grande conteúdo religioso.

O nascimento, o casamento e a morte. Viver consistia em passar essas etapas, ou melhor, essas sequências cerimoniais que tornavam significativos o universo e a existência individual. Para tal, impunham-se a natureza limites que se expressavam em rituais de agregação, trânsito ou separação. ${ }^{46}$

Estes rituais tinham lugar, sobretudo, em ambientes partilhados pela comunidade (notadamente a Igreja, a praça e a rua). Todavia, mesmo quando ocorriam em ambientes privados (o salão da casa grande, o pátio da fazenda, a capela particular), não havia uma delimitação muito clara da privacidade dos anfitriões, de modo que a apropriação ritual desses espaços pela comunidade era quase total. A privacidade (leia-se a casa) era também feita de pequenos ritos cotidianos da existência; contudo, o limite entre essa existência privada e a vida pública era demasiado fluido. Dessa forma, a estes ritos particulares se integravam quase indistintamente os grandes ritos públicos de passagem, alguns dos quais diziam respeito ao tempo de morrer.

A partir da virada do século XVIII para o XIX, essas práticas de sociabilidade públicas foram paulatinamente abandonadas, ou transferidas, em parte ou no todo, para o espaço doméstico. Para Luiz Mott ${ }^{47}$, a falta de compostura dos participantes dessas cerimônias - quer pela falta de constrição religiosa, quer pelos flertes maliciosos - forçou com que o espaço dos cerimoniais públicos se deslocasse para dentro do lar, em oposição a uma religiosidade propriamente privada. Dessa forma, os espaços de sociabilidade pública foram cada vez mais rareando, ao mesmo tempo em que se consolidava o papel da casa 
enquanto espaço de convivência tipicamente familiar, cada vez mais refratário a apropriações por parte da comunidade.

$\mathrm{Na}$ contramão do processo descrito acima, a experiência da morte ainda era intensamente coletiva no século XIX. Já foi mencionada que a principal atribuição das irmandades religiosas era a assistência às exéquias de seus membros, obrigação que se estendia ao momento anterior a elas: o da agonia. Contudo, não eram apenas os membros das irmandades que tomavam parte nos ritos de morte de seus membros: toda a comunidade era convidada a fazer o mesmo. Nesse período, quando se aproximava o fim, o doente não se isolava num quarto de hospital, mas antes "[...] esperava a morte em casa, na cama em que dormia, presidindo a própria morte diante de pessoas que circulavam incessantemente em torno de seu leito" 48 . Todas as providências antes da morte do moribundo eram tomadas por ele no ambiente de sua casa - mais precisamente em seu quarto, onde tradicionalmente o doente aguardava por sua morte no leito ${ }^{49}$. Ali, em geral, ele mandava escrever seu testamento, o que representava o ato inaugural de sua morte.

Quando a hora derradeira se aproximava, o pároco vinha até a casa do moribundo para administrar-lhe os últimos sacramentos antes da morte cristã. Estes eram, para os cristãos, símbolo do encontro de Deus com o homem em momentos de demonstração de fé. Thomas Ewbank, viajante norte-americano, assim descreveu a procissão do Viático nas ruas do Rio de Janeiro imperial:

Saindo à noite com um amigo, vimos um padre de cabeça coberta, num carro, acompanhado de três negros seminus. De cada lado do veículo, junto à porta, ia um negro com uma grande vela na mão; adiante, trotava um terceiro, tocando uma sineta. Era, ao que me informaram, o Viático, que o padre ia ministrar a um doente ou moribundo 50 .

Os momentos de doenças graves ou fatais eram bastante propícios para essas demonstrações, haja vista o grande interesse do doente em obter uma "boa morte". Assim, o pároco era chamado a visitá-lo e ministrar-lhe a penitência, a eucaristia e a extrema-unção, a fim de garantir-lhes uma "passagem" tranquila ${ }^{51}$. Em algumas oportunidades, o mesmo pároco que administrava os últimos sacramentos fazia às vezes de testamenteiro ${ }^{52}$. Dessa forma, o ato de testar frequentemente esteve relacionado ao início aos trabalhos do funeral, o que contribuía para estabelecer uma forte continuidade ritual entre testar, agonizar e morrer; em suma, entre os ritos ante morten (que tinham lugar apenas no espaço doméstico) e os post morten (que faziam a transição da casa para o espaço público).

Além do pároco e do testamenteiro, o doente recebia a visita de parentes, vizinhos, 
membros de sua irmandade, entre outros: toda uma assistência passava pelo quarto do doente em cerimoniosa contrição, acompanhando a agonia do moribundo ${ }^{53}$. "A casa se enchia de gente prestimosa e curiosa. [...] uma tomava conta da roupa do doente, lavando, fervendo e passando. Outra arrumava tudo para quando chegasse a hora de vestir o cadáver" ${ }^{24}$. Sem dúvida, a "boa morte" não era solitária. Em 1802, o viajante inglês, Thomas Lindley, em passagem por Porto Seguro, atestou esse ritual coletivo em torno do moribundo:

[...] quarto fechado onde não penetrava o ar puro e a luz; apenas uma vela era mantida sobre sua cabeça, enquanto ele jazia imóvel numa grande cama [...] $\mathrm{Na}$ parte superior da cama estavam colocadas diversas pequenas imagens e outras relíquias. [...] $\mathrm{O}$ aposento, cheio de parentes, visitas e criados, estava muitíssimo quente e abafado (grifo nosso) ${ }^{55}$.

É importante ressaltar que todas essas cerimônias de morte, que tinham lugar na casa do doente, no quarto do doente, eram presididas pelo próprio moribundo. Era dele o papel de orientar os membros da comunidade a tomar todas as providências a fim de garantir sua salvação depois da morte. E esse papel, ele o exercia fundamentalmente por meio do seu testamento, o qual respondia à expectativa cristã de garantir, diante da angústia da morte, certa previsibilidade por meio do estabelecimento de ritos apropriados. Contudo, o testamento não era o único instrumento que permitia ao moribundo presidir a sua morte: o próprio corpo do defunto e o ambiente de sua casa também cumpriam o seu papel.

A escrita do testamento, a visita do pároco, as visitas já pesarosas de parentes e amigos: todos esses procedimentos operavam uma transformação na atmosfera da casa (mais especificamente do quarto) do doente, emprestando-lhe um ar solene e dramático. A casa do doente, antes um ambiente doméstico e profano, se transformava num local também sagrado, onde a comunidade poderia tomar parte nos ritos ligados à morte. A materialidade desse ambiente, transubstanciada em caráter excepcional, colaborava para a construção do próprio corpo do defunto; este, por sua vez, exercendo o papel de objeto central de culto no templo fúnebre em que se convertera a casa, contribuía para a produção da casa-templo. Uma profusão de outros objetos, usados no velório, também auxiliava na composição de ambos, o corpo do defunto e a casa-templo. Dessa forma, eles compunham uma sacralidade material, a qual suspendia temporariamente o caráter exclusivamente privado e profano da casa do defunto, o que lhe permitia dirigir a cerimônia na ausência do fiel já falecido. Essa sacralidade material exercia uma forte influência sobre a comunidade, conclamando-a a não somente tomar parte solidariamente nos ritos mortuários, mas, sobretudo, a observar os procedimentos 
fúnebres apropriados, lembrando-lhe obsessivamente de sua importância para a salvação da alma do fiel falecido.

\section{O ambiente doméstico: os ritos fúnebres}

Logo após a morte, prosseguia o ritual fúnebre doméstico, como continuação natural do dos ritos da agonia. A esse respeito, explica-nos Bayard que

Depois que deu o último suspiro, as portas da casa são abertas e permanecem assim durante toda a vigília fúnebre, como convite aos estranhos [...]. As folhas das janelas são encostadas, formando penumbra na sala mortuária. A vela acesa na soleira da janela é apagada; os círios acesos são postos em torno do corpo exposto. ${ }^{56}$

Em seguida, “processa-se [...] a lavagem do cadáver. [...] Às vezes, para a lavagem do defunto, precisam chamar alguém, um amigo ou parente do falecido" ${ }^{57}$. Os primeiros cuidados com o corpo cabiam, geralmente, às mulheres, pois "elas eram consideradas muito mais ligadas do que o homem ao ciclo - eterno retorno - que arrasta todos os seres da vida para a morte e da morte para a vida" ${ }^{\text {58 }}$. Logo depois de lavado, o corpo era conduzido do quarto para a sala da frente, o cômodo que dá para a rua e para estrada; ali se operava a transição completa do privado para o público, e o cômodo se investia da mais solene sacralidade. Segundo José de Souza Martins, o velório devia ser feito de modo que o corpo ficasse com os pés em direção à porta e a cabeça em direção ao interior da casa. Esse seria um modo de evitar que a alma se recusasse a abandonar a casa-templo após o velório, assim como a própria morte ${ }^{59}$.

A escolha da roupa mortuária era fundamental. Vestir mortalhas de santos era muito comum, principalmente aquelas relacionadas a determinados santos - como São Francisco, Santo Antônio ou Nossa Senhora da Conceição. Esse desejo era um dos principais a se registrar em testamento, tamanha sua importância na representação da "boa morte". Foi o caso de piraiense Belarmina Maria de Jesus, a qual, em 1845, determinou em suas últimas vontades que "depois do meu falecimento meu corpo será mortalhado em habito de São Francisco" $" 60$.

Para a tradição católica "[...] com a permissão de Deus, ele [São Francisco] fazia expedições periódicas àquela zona celestial [o Purgatório] com o objetivo de resgatar almas ali encarceradas" ${ }^{61}$. Segundo João José Reis, o hábito franciscano era o preferido dos fieis soteropolitanos entre 1800 e 1836 (26\% da preferência), ao passo que 69\% do universo global de testadores determinava em suas últimas vontades a mortalha com a qual ser sepultado, a 
maioria branca ou de outros santos ${ }^{62}$. Para o Rio de Janeiro, Cláudia Rodrigues nos informa que a mortalha de São Francisco e suas denominações - da Penitencia e das Chagas - era a preferência de $8,3 \%$ dos fieis entre 1812 e 1885, o que lhe garantia a terceira posição. Perdia a preferência para a de Nossa Senhora da Conceição $(26,6 \%)$ e a de Santo Antonio $(26,5 \%)^{63}$. Em Piraí, no período compreendido entre 1835 e 1887, a mortalha branca era a mais preferida, sendo escolhida por $59 \%$ dos fieis ${ }^{64}$. A mortalha de São Francisco, por sua vez, também era bastante apreciada na freguesia, perfilando o segundo lugar na escolha dos devotos, com $10 \%$ da preferência. ${ }^{65}$

Independentemente do tipo de mortalha escolhida pelo testador, o fato é que, ao longo de boa parte do século XIX, tanto na freguesia de Piraí, quanto na Corte ou em Salvador, pessoas escolhiam ser enterradas em mortalhas que ora evocavam seus santos de devoção, ora a beatitude do corpo amortalhado. Dessa forma, a minúcia da escolha da mortalha pode ser entendida como uma representação do desejo de graça junto a Deus, especialmente a mortalha de santo, que de alguma forma antecipava a fantasia de reunião à corte celeste ${ }^{66}$.

Outros detalhes do funeral doméstico eram, em geral, deixados a cargo do armador funerário.

[...] como o preço dos enterros corresponde a todas as variações possíveis de pompa, dizem-lhe que prepare um de tantos mil-réis. Deixa-se tudo então por conta do armador. $\mathrm{O}$ corpo de defunto é sempre colocado na melhor peça da casa, e raramente fica mais de trinta e seis horas [...]. Se a pessoa morta era casada, os familiares dependuram à porta da rua um festão de fazenda preta e dourada. Para os solteiros, lilás e negro; para as crianças, branco ou azul e dourado. Os ataúdes dos casados são invariavelmente pretos; jamais, porém, os dos solteiros, que são vermelhos, roxos ou azuis. Os padres são levados ao tumulo em caixões com uma grande cruz pintada; mas os leigos não podem usar tais símbolos ${ }^{67}$.

A "armação da casa" era muitas vezes de grande luxo, feita por tecidos finos bordados e demais objetos. Rico ou pobre, carecia que até a hora do enterro o morto ficasse protegido pelo ambiente lutuoso. As famílias cariocas, com antecedência, mandavam a um padre que dissesse a missa pelo defunto, e chamasse "[...] outros armadores, para que fossem armar à frente das catacumbas murais e as banquetas, colocando sobre estas as urnas funerárias, com inscrições e fechos de prata, circuladas de castiçais e serpentinas do mesmo metal, com velas de cera" ${ }^{68}$. Thomas Ewbank nos informa que, "se forem necessários mais cachos para os cabelos, disso se encarrega o armador funerário, bem como de rouge para as faces e pó para o pescoço e os braços" ${ }^{\prime 69}$. Por essa passagem, podemos perceber o tamanho da responsabilidade dos armadores no trato com o defunto, bem como a minúcia com que 
desempenhavam o seu papel. Não à toa, frequentemente os gastos com a armação funerária eram faustosos.

Nem sempre a armação funerária era tão rica. Contudo, mesmo no interior da província fluminense, uma pessoa de posses não negligenciava a armação de seu próprio funeral. Na tabela abaixo, produzida a partir do recibo de prestação de serviço anexado ao inventário de Dona Possidônia Maria do Rosário (1857), podemos observar os gastos que foram feitos em seu funeral.

Tabela 1: descrição dos gastos fúnebres de Possidonia Maria do Rosário

\begin{tabular}{|l|c|l|c|}
\hline Medida & Quant. & \multicolumn{1}{|c|}{ Objeto } & Valor total \\
\hline Côvado & 4 & Meriní frances bom & $22 \$ 000$ \\
\hline Côvado & 6 & Setim branco & $9 \$ 600$ \\
\hline Côvado & 1 & Setim roxo & $1 \$ 600$ \\
\hline Vara & 5 & Renda fina larga & $10 \$ 000$ \\
\hline Vara & 3 & Renda fina estreita & $1 \$ 500$ \\
\hline Unidade & 1 & Cordão para hábito & $1 \$ 000$ \\
\hline Unidade & 1 & Meias pretas & 640 \\
\hline Unidade & 1 & Sapatos de verniz & $2 \$ 800$ \\
\hline Libra & 3 & Cera para casa onde estava o corpo & $6 \$ 000$ \\
\hline Unidade & 43 & Cartas expressas para convite & $4 \$ 300$ \\
\hline Garrafa & 1 & Água de Labarraque & $3 \$ 500$ \\
\hline Garrafa & 1 & Alfazema & 320 \\
\hline Côvado & 7 & Paninho preto & $1 \$ 680$ \\
\hline Côvado & 9 & Baeta preta & $8 \$ 640$ \\
\hline Varas & 22 & Galão & $8 \$ 600$ \\
\hline Unidade & 1 & Caixão forrado de casimira fina de renda & $80 \$ 000$ \\
\hline Libra & 6 & Cera para a irmandade do Sant. Sacramento & $12 \$ 000$ \\
\hline Libra & 3 & Padres e sacristão & $7 \$ 000$ \\
\hline Libra & 7 & Distribuir ao povo & $15 \$ 500$ \\
\hline xxx & xxx & A importância que cobrou o cônego & $47 \$ 600$ \\
\hline xxx & xxx & A importância de que seu ao padre Antonio & $25 \$ 000$ \\
\hline Xxx & $\mathrm{xxx}$ & A importância que se deu ao padre & $20 \$ 000$ \\
\hline Xxx & $\mathrm{xxx}$ & A importância que se deu ao sacristão & $19 \$ 200$ \\
\hline SUBTOTAL & $\mathbf{3 3 2 \$ 3 8 0}$ \\
\hline
\end{tabular}

FONTE: Arquivo Municipal de Piraí. Inventario de Possidônia Maria do Rosário. Fundo Judiciário. Serie cível. Caixa 18, no 004.01.114.168.

Analisando o recibo dos gastos feitos para o arranjo do funeral, percebemos que este esteve a cargo do testamenteiro e neto, Antônio de Abreu Guimarães. Ele seguiu as últimas 
vontades expressas no testamento da falecida avó, que pediu que seu enterro fosse " [...] feito sem pompa, porém com honestidade" ${ }^{\text {70 }}$. De fato, os gastos com o velório e enterro foram modestos. A título de comparação, a escrava Marcelina, que pertencia à falecida e já contava com a idade de 50 anos e não possuía uma das vistas, valia 300\$000; portanto, pouco menos que a quantia gasta no funeral de Dona Possidônia, que ainda possuía em seu plantel escravos de mais valor. Se compararmos essa quantia a todos os bens levantados, percebemos que somente uma ninharia fora gasta pelos herdeiros, a quem, entretanto, ela legou uma pequena fortuna avaliada em 20:168\$680 $0^{71}$.

Porém, mesmo que modesto, o evento doméstico recebeu a devida armação fúnebre. Os panos fúnebres estiveram presentes no funeral, com diversidade de tamanhos e cores para compor o ambiente lutuoso. Infelizmente as fontes não relatam qual teria sido a mortalha, mas sabemos que 43 testemunhas estiveram em seu velório. Os gastos com cartas-convites demonstram a importância ritual da presença de parentes e amigos para as orações fúnebres pela alma da falecida. Esta deixou registrado no testamento que desejava que seu corpo fosse "[...] acompanhado pela irmandade do Santíssimo de que se minha memória não falhe sou irmã, ${ }^{, 72}$, e de fato a Irmandade do Santíssimo Sacramento acompanhou seu velório e enterro. O detalhe mais importante: todo velório ocorreu em casa iluminada por 3 libras de cera no valor $6 \$ 000$

Todos os gastos do testamenteiro foram encomendados ao comerciante Antônio Maria de Souza. Não sabemos até o presente momento da pesquisa se ele era somente dono da loja dos produtos fúnebres ou se fazia também os serviços de armação fúnebre. Entretanto, sabemos que, através dele, contratavam-se não somente objetos (como as tábuas para a confecção do caixão, cujo valor foi $2 \$ 000)$, mas diversos serviços fúnebres, como a presença dos religiosos. A falecida pediu um velório com "honestidade", ou seja, à altura de seu status social e seguindo os ritos católicos da boa morte. Por isso, não faltaram religiosos no funeral. Cônegos, padres e sacristãos eram figuras importantes, não somente para impressionar as testemunhas, mas também por serem considerados "mediadores privilegiados da salvação"73.

Um fato que nos chama a atenção é a presença, no recibo do arranjo fúnebre, do item “água de Labarraque”. A Revista Médica Fluminense, publicada em fevereiro de 1841, nos informa que o produto químico era usado para "destruir os miasmas, que se desenvolvem das matérias evacuadas"74. Observamos assim que, nos meados do século XIX, já havia certa preocupação em prevenir que prováveis doenças exaladas pelo corpo não infectassem os vivos. Isso representava uma incipiente intrusão do discurso médico nas práticas fúnebres e 
no imaginário popular.

Ate então, pensava-se nos trópicos coloniais que os corpos estavam sob intensa influência celestial ou infernal. Nesse contexto, "a doença era, muitas vezes, percebida como a prova da ira de Deus"75, e não como algo diretamente associado às características mais mundanas da morte. De todo modo, o século XIX marca, para o Brasil, uma transformação no âmbito das práticas de cura. A vinda da família da Corte portuguesa à cidade carioca, e a subsequente independência do Império do Brasil, levariam a criação das Faculdades de Medicina do Rio de Janeiro e da Bahia, em 1832. Desde sua criação, até meados do século, essas instituições conseguiriam monopolizar duas importantes tarefas: imporem-se como instrumento da política imperial da saúde pública, por um lado; e tornarem-se o principal árbitro das inovações médico-cientificas, por outro lado $^{76}$. Após a instalação dessas faculdades, o objetivo da medicina brasileira deslocou-se paulatinamente da doença para a saúde, intervindo e regulamentando o espaço público, a higienização dos corpos e, inclusive, os costumes fúnebres, muitas vezes considerados "atrasados". Não seriam ao acaso as inúmeras críticas médicas cariocas e baianas contra as práticas fúnebres populares, bem como a seus representantes: as irmandades ${ }^{77}$.

No entanto, a visão médica rivalizaria por longo tempo ainda com a tradição popular pelo monopólio legítimo dos discursos e práticas funerárias. Aqui, o inventário de Dona Possidônia torna-se exemplar desse embate. Ao mesmo tempo em que este contemplou uma inovação médico cientifica - a água de Labarraque -, ele também manteve o uso de uma grande profusão de objetos que já tomavam assento ao lado do seu corpo antes da intromissão médica nos funerais da freguesia de Piraí, tais como a mortalha, panos de cores variadas, caixões, velas etc. Para além de uma contradição evidente, vemos aqui uma persistência de tradições muito antigas no trato funerário, as quais quase silenciam uma ainda pequena fratura inserida pelo discurso médico.

Em relação a esses objetos que tradicionalmente acompanharam o corpo de Dona Possidônia, podemos dizer que, mais do que representar o estado de morte em que a pessoa velada se encontrava, eles construíam o próprio morto: sem eles, o defunto não poderia ser o que era ${ }^{78}$. Nesse sentido, a mortalha - como os demais objetos - não apenas representava a aura de santidade a que aspirou o defunto quando dela fez escolha em vida; ela, em suma, constituía o próprio corpo do defunto, construindo um morto santificado, pronto para tomar seu lugar na corte celestial. Essa visão reconfortava os presentes. Por meio desses objetos, fortalecia-se sua crença na salvação, o que os ajudava a lidar com a crise que representava a 
morte de um membro da comunidade.

Nas sociedades tradicionais, existem "lugares privilegiados, ou sagrados, ou proibidos, reservados aos indivíduos que, em relação à sociedade e ao meio humano no interior do qual vivem, se encontram em estado de crise" ${ }^{\text {} 79}$. Esse estado de crise propicia a criação de um espaço concreto de exceção, em que as regras do convívio social são temporariamente suspensas, e no qual " [...] todas as representações se encontrariam presentes, causando contestações, fragmentações e inversões de regras devido aos seus conflitos" ${ }^{\text {" }}$. Nesse sentido, do mesmo modo que o século XX viu nos hospitais espaços heterotópicos de crise para os doentes agonizantes, no século XIX eram as casas desses doentes que se transformavam nesse tipo de ambiente de exceção. Por meio de uma série de rituais que se desenrolavam ainda durante a agonia e prosseguiam após a morte do doente, esse espaço usualmente doméstico e profano era subitamente convertido num ambiente sagrado em que o ritual da morte (notoriamente público) podia se desenrolar. Um ambiente de exceção, construído pela justaposição em um local real de elementos de vários espaços que são em si mesmos incompatíveis; onde os limites do público e do privado, do sagrado e do profano, que normalmente estariam separados em alocações distintas, eram confundidos e misturados.

Nesse ambiente, o corpo santificado do defunto ocupava lugar central na devoção fúnebre. Cumpria o papel de compor, juntamente com os outros atavios do velório, uma sacralidade material, que convertia em templo a casa do fiel falecido. E nesse templo em que se convertia a casa desde a agonia do moribundo - esse "espaço sagrado [que] tem um valor existencial para o homem religioso" ${ }^{\prime 81}$ - a comunidade era convidada a tomar parte na intimidade do doente. Suas últimas expiações se transformavam num espetáculo público, uma espécie de última lição que o moribundo acrescentava à pedagogia da morte da comunidade em que viveu. A solenidade que tomava conta do seu quarto de doente agonizante perdurava pelos momentos que sucediam sua morte; os presentes quase podiam observar as hostes de anjos e demônios que lá disputavam a alma do moribundo ${ }^{82}$. Ares de sacralidade se apossavam desse ambiente profano, e dele só se retiravam algum tempo após o corpo ser dele retirado.

\section{Considerações Finais}

Na sociedade brasileira do século XIX, os funerais se revestiam de um caráter de espetáculo público. Neles, toda a comunidade tomava parte, seja no cortejo do defunto, seja 
na assistência à missa de corpo presente, no sepultamento, ou nos sufrágios por sua alma. Contudo, apesar de o bojo central desses ritos de morte se desenvolver em espaços destinados ao convívio social (a Igreja, a rua, a praça, o cemitério), era no ambiente doméstico da casa do doente agonizante que a experiência da morte se iniciava.

A iminência da morte punha o indivíduo moribundo em estado de crise em relação ao meio em que vivia. Contudo, essa crise era neutralizada pela conversão da casa do doente, normalmente um espaço doméstico e profano, num ambiente sagrado em que ritos de morte poderiam ocorrer e dos quais a comunidade poderia participar. Essa conversão se operava por meio de uma série de atitudes rituais - a escrita do testamento, a visita do viático, a recepção dos sacramentos, a visita de parentes e membros da comunidade em atitude de despedida que ressignificavam a iminência física da morte, criando uma expectativa de transcendência atrelada à crença de uma boa morte.

Entretanto, não eram apenas as atitudes rituais que convertiam a casa do doente num templo fúnebre. Antes, uma série de objetos funerários, bem como a própria presença do corpo do defunto (composto e santificado por outros objetos), colaborava para construir uma sacralidade material. Essa sacralidade transubstanciava a casa do doente em caráter excepcional. Esse espaço, antes interditado à comunidade, agora era apropriado por ela como parte de um espaço sacralizado especialmente para o culto da boa morte. Uma atmosfera de solenidade, densa e pesarosa, inundava o ambiente. Nele, a escatologia cristã era, ao mesmo tempo, representada e reproduzida. O rito de morte, em suma, convertia-se numa celebração da crença inabalável de que, um dia, todos seriam salvos e descansariam na glória de Deus. O potencial desagregador da morte para o corpo social dava lugar a um sentimento de pertencimento a algo maior, que transcendia a natureza individual de cada um. A morte, em suma, era um momento de a comunidade "religar-se" consigo mesma e com o divino.

\section{Nota}

\footnotetext{
${ }^{1}$ BLOCH, Marc. Apologia da História. Trad. André Telles. Rio de Janeiro: Jorge Zahar, 2001, p. 54.

2 MICHELET, Jules. O Povo. São Paulo: Martins Fontes, 1988.

${ }^{3}$ BURCKHARDT, Jacob. A cultura do Renascimento na Itália: um ensaio. São Paulo: Cia. Das Letras, 2003.

${ }^{4}$ BURKE, Peter. A Escola dos Annales: a revolução francesa da historiografia. 2ed. São Paulo: Unesp, 1991, pp. 11-12.

${ }^{5}$ BLOCH, Marc. Op. cit.

${ }^{6}$ FEBVRE, Lucien. Combates pela História. Lisboa (Port.): Presença, 1989.

${ }^{7}$ BURKE, Peter. Op. cit.

${ }^{8}$ DOSSE, François. A história em migalhas: dos Annales a nova historia. Trad. Dulce Oliveira Amarante dos Santos. São Paulo: EDUSC, 2003.

${ }^{9}$ VOVELLE, Michel. Ideologias e mentalidades. 2ed. São Paulo: Brasiliense, 1991, p. 134.
} 
10 BRITO, Nercinda P. S. Um olhar historiográfico: morte e doença na historiografia contemporânea. Contraponto. Teresina/PI, no 1, v. 1, jun/2011, p. 52.

${ }^{11}$ ARIÈS, Philippe. História da morte no Ocidente. Trad. Priscila V. Siqueira. Rio de Janeiro: Nova Fronteira, 2012.

${ }^{12}$ REIS, João José. A morte é uma festa: ritos fúnebres e revolta popular no Brasil do século XIX. $5^{\mathrm{a}}$ ed. São Paulo: Cia. das Letras, 1991.

${ }^{13}$ CAMPOS, Adalgisa Arantes. As Irmandades de São Miguel e as Almas do Purgatório: culto e iconografia no Setecentos mineiro. Belo Horizonte: C/Arte, 2013.

${ }^{14}$ RODRIGUES, Cláudia. Nas fronteiras do Além: a secularização da morte no Rio de Janeiro (séculos XVIII e XIX). Rio de Janeiro: Arquivo Nacional, 2005.

${ }^{15}$ VAILATI, Luiz Lima. A morte menina: infância e morte infantil no Brasil dos oitocentos (Rio de Janeiro e São Paulo). São Paulo: Alameda, 2010.

${ }^{16}$ BARROS, José D’Assunção. O campo da historia: especialidades e abordagens. 9ed. Petrópolis: Vozes, 2013, p. 160.

${ }^{17}$ Em um texto originalmente escrito como uma conferência proferida na Tunísia, em 1967, Foucault define o conceito de heteropia como referente a "[...] lugares reais, lugares efetivos, lugares que são desenhados na própria instituição da sociedade e que são espécies de contra-alocações, espécies de utopias efetivamente realizadas, nas quais as alocações reais, todas as outras alocações reais que podem ser encontradas no interior da cultura, são simultaneamente representadas, contestadas e invertidas; espécies de lugares que estão fora de todos os lugares, embora sejam efetivamente localizáveis”. (FOUCAULT, Michel. De espaços outros. Estudos avançados. v. 27, n. 79, São Paulo, 2013, pp. 115-116)

${ }^{18}$ RODRIGUES, Cláudia. O uso de testamentos nas pesquisas sobre atitude diante da morte em sociedades católicas de Antigo Regime. In: ; et al. Últimas vontades: testamentos, sociedade e cultura na América ibérica (séculos XVII e XVIII). Rio de Janeiro: Mauad X, 2015, p. 17.

${ }^{19}$ CHIAVENATO, Júlio J. A morte: uma abordagem sociocultural. São Paulo: Moderna, 1998, p. 37.

${ }^{20}$ VIDE, Sebastião Monteiro da. Constituição primeira do Arcebispado da Bahia. São Paulo: Typographia 2 de Dezembro de Antonio Louzada Antunes, 1853, Livro IV, Titulo XXXIX.

${ }^{21}$ V. BRUNO, Aguiomar Rodrigues. Tractatus de arte et scientia bene moriendi: a literatura pedagógica da morte no interior fluminense oitocentista (freguesia de Piraí). Espacialidades. Vol. 8, n. 1, 2015, pp. 59-62.

${ }^{22}$ BRUNO, Aguiomar R.; PEREIRA, Geovani D. A liturgia da boa morte: representações e práticas fúnebres nos testamentos da Freguesia de Piraí/RJ (1830-1850). Bilros - História, Sociedade, Cultura. Fortaleza, v. 4, n. 6, jan.- jun. 2016, pp. 207-233.

23 MUAZE, Mariana. Novas considerações sobre o Vale do Paraíba e a dinâmica imperial. In: MUAZE, Mariana; SALLES, Ricardo (org.). O vale do Paraíba e o império do Brasil nos quadros da segunda escravidão. Rio de Janeiro: 7Letras, 2015, p. 65.

${ }^{24}$ CAMPOS, Thiago. A força da escravidão ao sul do Rio de Janeiro. In: MUAZE, Mariana; SALLES, Ricardo (org.).O vale do Paraíba e o império do Brasil nos quadros da segunda escravidão. Rio de Janeiro: 7Letras, 2015, p. 315. Para saber mais sobre o processo de emancipação do povoado de Pirai, veja: BRUNO, Aguiomar Rodrigues. Nas fronteiras do poder: conflito e emancipação numa província fluminense (século XIX). Revista Semina. V14, no 2, 2015.

${ }^{25}$ REIS, João José. A morte é uma festa..., p. 95.

${ }^{26}$ XAVIER, Pedro do Amaral. Imagens da morte na arte: dos finais da Idade Média ao Barroco. In: COELHO, A. M. (org.). Atitudes perante a morte. Coimbra: Minerva, 1991, p. 31.

${ }^{27}$ TURNER, Victor. Floresta de símbolos. Niterói: EDUFF, 2005.

${ }^{28}$ RODRIGUES, José Carlos. Tabu da morte. 2ed. Rio de Janeiro: Fiocruz, 2006, p. 21.

${ }^{29}$ Arquivo Municipal de Piraí. Testamento de Matheus Rodrigues Pinheiro. Fundo Judiciário. Serie Civil. Caixa 4, no 004.01.02.180.

${ }^{30}$ PRIORE, Mary Del. Ritos da vida privada. In: NOVAIS, F.; SOUZA, L. de Mello. (org.). Historia da vida privada. Vol 1. São Paulo: Companhia das Letras, 1997, p. 321.

${ }^{31}$ PAGOTO, Amanda A. Do âmbito sagrado da Igreja ao cemitério público: transformações fúnebres em São Paulo (1850-1860). São Paulo: Arquivo do Estado, 2004, p. 33.

${ }^{32}$ Historicamente, a irmandade do Santíssimo Sacramento era considerada a organização religiosa leiga mais importante. Segundo Fritz Teixeira de Salles, "nos primeiros anos de povoamento eram obrigatórias as irmandades do Santíssimo Sacramento, que simbolizam a autoridade suprema da Corte celeste e que arregimentam as pessoas de maior projeção do arraial" (SALLES, Fritz T. Associações religiosas no ciclo do ouro. 2ed. São Paulo: Perspectiva, 2007, p. 54). Julita Scarano também enfatiza que "[...] a mais importante irmandade de brancos foi a do Santíssimo Sacramento [...]" (SCARANO, Julita. Devoção e escravidão. São Paulo: Companhia Editora Nacional, 1975, p.33). 
${ }^{33}$ REIS, João José. A morte é uma festa... p. 153.

${ }^{34}$ MOLLAT, Michel. Os pobres na Idade Média. Rio de Janeiro: Campus, 1989, p. 51.

${ }^{35}$ MARANHÃO, José Luiz de Souza. O que é morte. São Paulo: Brasiliense, 1985, p. 34.

${ }^{36}$ Arquivo Municipal de Piraí. Compromisso da irmandade do Santíssimo Sacramento de Piraí. (1860). Fundo Religioso. Série Diversa. Caixa 2. Nº01.0.99, p. 4.

${ }^{37}$ TAVARES, Mauro Dillman. Irmandades, Igreja e devoção no sul do Império do Brasil. São Leopoldo: Oikos, 2008 , p. 248.

${ }^{38}$ REIS, João José. O cotidiano da morte no Brasil oitocentista. In: NOVAIS, Fernando A. (org.). História da vida privada. Vol 2. 4ed. São Paulo: Companhia das Letras, 1997, p. 97.

${ }^{39}$ Idem.

${ }^{40}$ GRZYWACZ, José. Nossa senhora do perpetuo socorro, mãe companheira. São Paulo: Paulus, 2016, p. 23.

${ }^{41}$ Advertia o Retiro Espiritual, uma espécie de "manual da boa morte" muito difundido nesse período: "fazei o vosso testamento, em quanto estais com saúde, em quanto estais com o vosso juízo" (Biblioteca Nacional do Rio de Janeiro. Retiro Espiritual para hum dia de cada mez. Obra muito útil para toda a sorte de pessoas, e principalmente para aqueles, que desejão segurar huma boa morte. $5^{\mathrm{a}}$ ed. Lisboa: Regia Officina Typográfica, 1794-1795, p. 491). Os manuais da boa morte eram um tipo de literatura devocional muito difundido, desde o século XVI; seu intuito era o de ensinar as pessoas a se preparar para uma boa morte, além de orientar aqueles que assistiriam os moribundos em sua hora derradeira - tudo de acordo com os dogmas propalados pela fé católica.

${ }^{42}$ Arquivo Municipal de Piraí. Testamento de Manoel José Fernandes Alves. Fundo Judiciário. Serie Civil. Caixa 4, no 004.01.02.217.

${ }^{43}$ MARTINS, Jose de Souza (Org.). A morte e os mortos na sociedade brasileira. São Paulo: Hucitec, 1983, p. 263.

${ }^{44}$ COSTA, Célia L. Intimidade versus interesse público: a problemática dos arquivos. Estudos históricos, n. 21, 1998, p. 190.

${ }^{45}$ PERROT, Michelle. Outrora, em outro lugar. In: História da vida privada: da revolução Francesa à Primeira Guerra. Vol. 4. Trad. Denise Bottmann. São Paulo: Cia das Letras, 2009, p. 14.

${ }^{46}$ PRIORE, Mary Del. Op. cit., p. 309.

${ }^{47}$ MOTT, Luiz. Cotidiano e vivencia religiosa: entre a capela e o calundu. In: NOVAIS, F.; SOUZA, L. de Mello. (org.). História da vida privada. Vol 1. São Paulo: Companhia das Letras, 1997, pp. 161-162.

${ }^{48}$ REIS, João José. O cotidiano da morte... p. 104.

${ }^{49}$ ARIÈS, Philippe. Op. cit., pp. 55-57.

${ }^{50}$ EWBANK, Thomas. A vida no Brasil ou diário de uma visita ao país do cacau e das palmeiras. Tradução: Homero de Castro Jobim. Rio de Janeiro: Conquista, 1973, p. 74.

${ }^{51}$ RODRIGUES, Cláudia. Lugares dos mortos na cidade dos vivos: tradições, e transformações fúnebres no Rio de Janeiro. Rio de Janeiro: Secretaria Municipal de Cultura, 1997, p. 176.

52 A esse respeito, as "Constituições Primeiras do Arcebispado da Bahia" mencionava que "[...] poderão os Parochos escrever nos testamentos, que fizerem, que se fação os officios, e sufragios costumados, ainda que elles mesmos os hajão de cumprir [...]". Além disso, estabelecia que "[...] quando algum Parocho ou outro Clerigo, que não for Letrado, e versado em fazer testamentos, for chamado para fazer algum, procure com todo o cuidado saber como se deve fazer, para ficar valioso [...]”. (VIDE, Sebastião Monteiro da. Op. cit., Livro IV, Título XXXIX).

53 ARANHA, Maria L. A.; MARTINS, Maria H. P. A morte. In: (org.). Filosofando: introdução à filosofia. 2ed. São Paulo: Moderna, 1993, p. 103.

${ }^{54}$ VIANNA, Hildegardes. A Bahia já foi assim. Salvador: Ed. Itapuã, 1973, p. 53.

55 LINDLEY, Thomas. Narrativa de uma viagem ao Brasil. São Paulo: Ed. Nacional, 1969, p. 45.

${ }^{56}$ BAYARD, Jean-Pierre. Sentidos oculto dos ritos mortuários: morrer é morrer? São Paulo: Paulus, 1996, p. 135.

57 ARAUJO, Alceu Maynard. Folclore Nacional. Vol. III. São Paulo: Ed. Melhoramentos, 1964, p. 55.

58 DELUMEAU, Jean. Historia do medo no Ocidente (1300-1800): uma cidade sitiada. Trad. Maria Lúcia Machado. São Paulo: Companhia das Letras, 2009, p. 465.

${ }^{59}$ MARTINS, Jose de Souza. Op. cit., p. 265.

${ }^{60}$ Arquivo Municipal de Piraí. Testamento de Belarmina Maria de Jesus. Fundo Judiciário. Serie Civil. Caixa 1, $\mathrm{n}^{\circ}$ 004.01.02.32.

${ }^{61}$ REIS, João José. O cotidiano da morte..., p. 112.

${ }^{62}$ Idem, p. 116.

${ }^{63}$ RODRIGUES, Cláudia. Lugares dos mortos..., p. 199. 
${ }^{64}$ Os registros do Livro 2 da Matriz de Piraí revelam à escolha pela mortalha branca no total de 441 assentos, correspondendo a 59\% dos fieis. Desse total, 344 registros são referentes à inumação de escravos. Para João José Reis, "Mortalhas brancas de tecido de algodão ordinário eram populares entre os africanos no Rio e em Salvador, pois o branco é a cor fúnebre de muitos grupos étnicos da África, como os nagôs, jejes, angolas, congos e os mulçumanos em geral. Para os nagôs, por exemplo, o branco se relaciona ao orixá Obatalá, ou Oxalá, o criador, que, na hora da morte, reivindica sua criação". (REIS, João José. O cotidiano da morte..., p. 11).

${ }^{65}$ Arquivo Municipal de Piraí. Livro 2 de óbito da igreja de Piraí (1835-1887). Fundo Religioso Diverso.

${ }^{66}$ REIS, João José. A morte é uma festa..., p. 124.

${ }^{67}$ EWBANK, Thomas. Op. cit., p. 77.

${ }^{68}$ FILHO, Mello Morais. Festas e tradições populares no Brasil. Brasília: Senado Federal, 2002, p. 226.

${ }^{69}$ EWBANCK, Thomas. Op. cit., p. 78.

${ }^{70}$ Arquivo Municipal de Piraí. Inventario de Possidônia Maria do Rosário. Fundo Judiciário. Serie cível. Caixa $18, \mathrm{n}^{\mathrm{o}}$ 004.01.114.168.

${ }^{71}$ Idem.

72 Ibidem.

${ }^{73}$ REIS, João José. O cotidiano da morte..., p. 120.

${ }^{74}$ REVISTA MÉDICA FLUMINENSE. Tratamento da dysenteria. $\mathrm{n}^{\circ}$ 11, vol 6, Fevereiro de 1841, p. 462.

75 RIBEIRO, Márcia Moisés. A ciência dos trópicos: a arte médica no Brasil do século XVIII. São Paulo: Hucitec, 1997, p. 72.

${ }^{76}$ EDLER, Flávio Coelho. A natureza contra o hábito: a ciência médica no Império. Acervo, rio de Janeiro, v. $22, \mathrm{n}^{\circ} 1$, p. 153-166, jan/jun 2009, p. 159.

${ }^{77}$ REIS, João José. A morte é uma festa...; RODRIGUES, Cláudia. Lugares dos mortos...

${ }^{78}$ MILLER, Daniel. Trecos, troços e Coisas. Trad. Renato Aguiar. Rio de Janeiro: Zahar, 2013, pp. 21-23.

${ }^{79}$ FOUCAULT, Michel. Op. cit., p. 116.

${ }^{80}$ VALVERDE, Rodrigo Ramos Hospodar Felippe. Sobre espaço público e heterotopia. Geosul. Florianópolis, v. $24, \mathrm{n}^{\mathrm{o}} 48, \mathrm{jul} / \mathrm{dez} 2009$, p. 11.

${ }^{81}$ ELIADE, Mircea. O sagrado e o profano: a essência das religiões. Trad. Rogério Fernandes. São Paulo: Martins Fontes, 1986, p. 36.

${ }^{82}$ ARIÈS, Philippe. Op. cit., pp. 52-57.

\section{Referências Bibliográficas}

ARANHA, Maria L. A.; MARTINS, Maria H. P. A morte. In: (org.). Filosofando: introdução à filosofia. 2ed. São Paulo: Moderna, 1993.

ARIÈS, Philippe. História da morte no Ocidente. Trad. Priscila V. Siqueira. Rio de Janeiro: Nova Fronteira, 2012.

BARROS, José D’Assunção. O campo da historia: especialidades e abordagens. 9ed. Petrópolis: Vozes, 2013.

BAYARD, Jean-Pierre. Sentidos oculto dos ritos mortuários: morrer é morrer? São Paulo: Paulus, 1996.

BLOCH, Marc. Apologia da História. Trad. André Telles. Rio de Janeiro: Jorge Zahar, 2001.

BRITO, Nercinda P. S. Um olhar historiográfico: morte e doença na historiografia contemporânea. Contraponto. Teresina/PI, no 1, v. 1, jun/2011.

BRUNO, Aguiomar R.; PEREIRA, Geovani D. A liturgia da boa morte: representações e práticas fúnebres nos testamentos da Freguesia de Piraí/RJ (1830-1850). Bilros - História, Sociedade, Cultura. Fortaleza, v. 4, n. 6, jan.- jun. 2016, pp. 207-233.

. Tractatus de arte et scientia bene moriendi: a literatura pedagógica da morte no interior fluminense oitocentista (freguesia de Piraí). Espacialidades. Vol. 8, n. 1, 2015. - Nas fronteiras do poder: conflito e emancipação numa província fluminense

(século XIX). Revista Semina. V14, nº 2, 2015. 
BURCKHARDT, Jacob. A cultura do Renascimento na Itália: um ensaio. São Paulo: Cia. Das Letras, 2003.

BURKE, Peter. A Escola dos Annales: a revolução francesa da historiografia. 2ed. São Paulo: Unesp, 1991.

CAMPOS, Adalgisa Arantes. As Irmandades de São Miguel e as Almas do Purgatório: culto e iconografia no Setecentos mineiro. Belo Horizonte: C/Arte, 2013.

CAMPOS, Thiago. A força da escravidão ao sul do Rio de Janeiro. In: MUAZE, Mariana; SALLES, Ricardo (org.). O vale do Paraíba e o império do Brasil nos quadros da segunda escravidão. Rio de Janeiro: 7Letras, 2015.

CHIAVENATO, Júlio J. A morte: uma abordagem sociocultural. São Paulo: Moderna, 1998.

COSTA, Célia L. Intimidade versus interesse público: a problemática dos arquivos. Estudos históricos, n, 21, 1998.

DELUMEAU, Jean. Historia do medo no Ocidente (1300-1800): uma cidade sitiada. Trad. Maria Lúcia Machado. São Paulo: Companhia das Letras, 2009.

DOSSE, François. A história em migalhas: dos Annales a nova historia. Trad. Dulce Oliveira Amarante dos Santos. São Paulo: EDUSC, 2003.

ELIADE, Mircea. O sagrado e o profano: a essência das religiões. Tradução: Rogério Fernandes. São Paulo: Martins Fontes, 1986.

FEBVRE, Lucien. Combates pela História. Lisboa (Port.): Presença, 1989.

FOUCAULT, Michel. De espaços outros. Estudos avançados. v. 27, n. 79, São Paulo, 2013, pp. 113-122.

GRZYWACZ, José. Nossa senhora do perpetuo socorro, mãe companheira. São Paulo: Paulus, 2016.

MARANHÃO, José Luiz de Souza. O que é morte. São Paulo: Brasiliense, 1985.

MARTINS, Jose de Souza (Org.). A morte e os mortos na sociedade brasileira. São Paulo: Hucitec, 1983.

MICHELET, Jules. O Povo. São Paulo: Martins Fontes, 1988.

MILLER, Daniel. Trecos, troços e Coisas. Trad. Renato Aguiar. Rio de Janeiro: Zahar, 2013.

MOLLAT, Michel. Os pobres na Idade Média. Rio de Janeiro: Campus, 1989.

MOTT, Luiz. Cotidiano e vivencia religiosa: entre a capela e o calundu. In: NOVAIS, F.; SOUZA, L. de Mello. (org.). História da vida privada. Vol 1. São Paulo: Companhia das Letras, 1997.

MUAZE, Mariana. Novas considerações sobre o Vale do Paraíba e a dinâmica imperial. In: ; SALLES, Ricardo (org.). O vale do Paraíba e o império do Brasil nos quadros da segunda escravidão. Rio de Janeiro: 7Letras, 2015.

PAGOTO, Amanda A. Do âmbito sagrado da Igreja ao cemitério público: transformações fúnebres em São Paulo (1850-1860). São Paulo: Arquivo do Estado, 2004.

PERROT, Michelle. Outrora, em outro lugar. In: História da vida privada: da revolução Francesa à Primeira Guerra. Vol. 4. Trad. Denise Bottmann. São Paulo: Cia das Letras, 2009.

PRIORE, Mary Del. Ritos da vida privada. In: NOVAIS, F.; SOUZA, L. de Mello. (org.). Historia da vida privada. Vol 1. São Paulo: Companhia das Letras, 1997.

REIS, João José. A morte é uma festa: ritos fúnebres e revolta popular no Brasil do século XIX. $5^{\text {a }}$ ed. São Paulo: Cia. das Letras, 1991.

. O cotidiano da morte no Brasil oitocentista. In: NOVAIS, Fernando A. (org.). 
História da vida privada. Vol 2. 4ed. São Paulo: Companhia das Letras, 1997.

RODRIGUES, Cláudia. Nas fronteiras do Além: a secularização da morte no Rio de Janeiro (séculos XVIII e XIX). Rio de Janeiro: Arquivo Nacional, 2005.

. O uso de testamentos nas pesquisas sobre atitude diante da morte em sociedades

católicas de Antigo Regime. In: ; et al. Últimas vontades: testamentos, sociedade e cultura na América ibérica (séculos XVII e XVIII). Rio de Janeiro: Mauad X, 2015.

. Lugares dos mortos na cidade dos vivos: tradições, e transformações fúnebres no

Rio de Janeiro. Rio de Janeiro: Secretaria Municipal de Cultura, 1997.

RODRIGUES, José Carlos. Tabu da morte. 2ed. Rio de Janeiro: Fiocruz, 2006.

SALLES, Fritz Teixeira. Associações religiosas no ciclo do ouro. 2ed. São Paulo: Perspectiva, 2007.

SCARANO, Julita. Devoção e escravidão. São Paulo: Companhia Editora Nacional, 1975.

TAVARES, Mauro Dillman. Irmandades, Igreja e devoção no sul do Império do Brasil. São Leopoldo: Oikos, 2008.

TURNER, Victor. Floresta de símbolos. Niterói: EDUFF, 2005.

VAILATI, Luiz Lima. A morte menina: infância e morte infantil no Brasil dos oitocentos (Rio de Janeiro e São Paulo). São Paulo: Alameda, 2010.

VALVERDE, Rodrigo Ramos Hospodar Felippe. Sobre espaço público e heterotopia. Geosul. Florianópolis, v. 24, nº 48, p 7-26, jul/dez 2009.

VOVELLE, Michel. Ideologias e mentalidades. 2ed. São Paulo: Brasiliense, 1991.

XAVIER, Pedro do Amaral. Imagens da morte na arte: dos finais da Idade Média ao Barroco. In: COELHO, A. M. (org.). Atitudes perante a morte. Coimbra: Minerva, 1991.

\section{Documentos e livros raros}

Arquivo Municipal de Piraí. Testamento de Matheus Rodrigues Pinheiro. Fundo Judiciário. Serie Civil. Caixa 4, $\mathrm{n}^{\circ}$ 004.01.02.180.

Arquivo Municipal de Piraí. Testamento de Belarmina Maria de Jesus. Fundo Judiciário. Serie Civil. Caixa 1, $\mathrm{n}^{\circ}$ 004.01.02.32.

Arquivo Municipal de Piraí. Testamento de Manoel José Fernandes Alves. Fundo Judiciário. Serie Civil. Caixa 4, $\mathrm{n}^{\mathrm{o}}$ 004.01.02.217.

Arquivo Municipal de Piraí. Inventario de Possidônia Maria do Rosário. Fundo Judiciário. Serie cível. Caixa 18, no 004.01.114.168.

Arquivo Municipal de Piraí. Testamento de Possidônia Maria do Rosário. Fundo Judiciário. Serie cível. Caixa 2, nº 004. 01. 02. 71.

Arquivo Municipal de Piraí. Compromisso da irmandade do Santíssimo Sacramento de Piraí. (1860). Fundo Religioso. Série Diversa. Caixa 2. No 001.0.99.

Arquivo Municipal de Piraí. Livro 2 de óbito da igreja de Piraí (1835-1887). Fundo Religioso Diverso.

Biblioteca Nacional do Rio de Janeiro. Retiro Espiritual para hum dia de cada mez. Obra muito útil para toda a sorte de pessoas, e principalmente para aqueles, que desejão segurar huma boa morte. $5^{\text {a }}$ ed. Lisboa: Regia Officina Typográfica, 1794-1795.

ARAUJO, Alceu Maynard. Folclore Nacional. Vol. III. São Paulo: Ed. Melhoramentos, 1964. EWBANK, Thomas. A vida no Brasil ou diário de uma visita ao país do cacau e das palmeiras. Tradução: Homero de Castro Jobim. Rio de Janeiro: Conquista, 1973.

FILHO, Mello Morais. Festas e tradições populares no Brasil. Brasília: Senado Federal, 2002. 
LINDLEY, Thomas. Narrativa de uma viagem ao Brasil. São Paulo: Ed. Nacional, 1969.

REVISTA MÉDICA FLUMINENSE. Tratamento da dysenteria. $\mathrm{n}^{\circ} 11$, vol 6, Fevereiro de 1841.

VIANNA, Hildegardes. A Bahia já foi assim. Salvador: Ed. Itapuã, 1973.

VIDE, Sebastião Monteiro da. Constituição primeira do Arcebispado da Bahia. São Paulo: Typographia 2 de Dezembro de Antonio Louzada Antunes, 1853. 